\title{
WORK MOTIVATION AND LABOUR PRODUCTIVITY GROWTH AMONG IT PROFESSIONALS IN CONTEMPORARY LATVIA
}

\author{
Svetlana Gribanova ${ }^{1}$, Mg.soc. ; Anna Abeltina ${ }^{2}$, Dr.oec. \\ 1,2Turiba University
}

\begin{abstract}
This paper is dedicated to the research of factors that drive work motivation of Information Technology (further in the text IT) professionals in Latvia and lead to the increase in labour efficiency. Various research works have proved relation of employees' motivation and work performance. However, No previous research was conducted in contemporary Latvia aiming at IT specialists.

The research is based on the results of survey of 1200 IT professionals in Latvia. Besides motivation factors, personal characteristics of Latvian IT professionals was given with the use of adapted Schwarz questionnaire. The data were studied through regression analysis, and factors that influence work motivation and work efficiency growth were found.
\end{abstract}

Key words: motivation, work efficiency, IT professionals.

JEL code: M15, O15, M12.

\section{Introduction}

Sustainable growth of Latvian economy in the era of new technologies demands the increase in labour productivity. Skilled labour force becomes one of the main drivers of economy together with technological development. IT specialists combine these two drivers. Their participation in developed economies increases each year. Despite the terrific growth in number of IT specialists in the EU by $36.1 \%$ from 2007 to 2017, Latvia has one of the lowest shares of IT specialists in the total employment - only $2.3 \%$ (Eurostat, 2018).

The goal of motivation is building an environment in which employees would strive to achieve goals by the most efficient way (Deci, E. L., Ryan, R. M., 2000). Various research works have proved that motivation of specialists in different sectors vary (Chaix-Couturier et al., 2000; Chowdhury, 2008; Drake, 2017; ). It can be explained by different qualities essential for jobs and values of employees. This is why focusing on IT specialists has scientific and practical interest.

\section{Theoretical framework}

Theories concerning work motivation have a long history and evolved during the last century. For a long time, it was believed that the only motivating factor for an effective performance was financial reward. The founder of the school of scientific management Frederick Taylor has developed a system of employees work organization that was based on interconnection between labour productivity and payment (Glaser, M., 1991). However, Mayo and Hawthorne experiments discovered significant influence of psychological factors on work performance (Trahair, R., Zaleznik, A., 2005). Over time different psychological theories of motivation appeared. They tried to study the structure of motivation process and motivation factors from various points of view (Kasser, T., Ryan, R. M. ,1993).

Motivation process can be generally described through defining basic concepts applied for its explanation: needs, motives and goals (Frager R., 1976; Frager R., Maslow A., 1987).

Motivation process in real life is much more complicated. Motives that drive human behaviours are unsTable and complicated. They are formed under the influence of system of internal and external factors such as talent, education, social status, financial status, public opinion and many others. Therefore, it is very difficult to predict human behaviour as a respond to different motivation factors. 
One of the main indicators of companies' efficiency is labour productivity. This indicator shows the efficiency of labour inputs. The effect caused by labour productivity growth influences the increase in employees' wages.

Labour productivity is an economic category that characterizes the efficiency of employees actions and results in the value of goods produced by an employee (Meyer, p. 2005).

Contemporary Latvia struggles low labour productivity in comparison with other developed countries. Factors that influence labour productivity include low efficiency of labour organization that doesn't meet expectations about comforTable working environment which is important for modern professional (Znotina D., Jermolajeva E., 2012).

The readiness of the employees to do their job is one of the most significant factors, which guarantees efficiency of performance of the company. Therefore, it is significant to understand what makes the employee work efficiently. Despite the fact that motivation is mostly subjective factor, performance is objective one. The connection between motivation and productivity is well explored in international economic sciences (Monese, Thwala, 2011, Jarkas, Bitar, 2012, Khan, Saleem, Umer, 2011).

\section{Data and methods}

The aim of the research was to analyse the labour motifs and stimuli for more efficient work of IT professionals. The tasks included determination of motivating stimuli; determination of factors, which might influence productivity of IT professionals (meaning factors, which, in their opinion, cause their will to perform better); analysis of value structure of IT professionals; creation of models which demonstrate how stimuli for increased productivity depend on motivating factors and value orientations of IT professionals.

Theoretical approaches and analysis of already conducted research works allowed formulating several hypotheses:

H1: Material stimuli are more effective for the married people and people with children;

$\mathrm{H} 2$ : Material stimuli are more relevant for people whose values are more connected with material wellbeing and hedonistic value setting;

H3: Type of work influences on type of stimuli for improving work productivity. Individuals doing creative job (creating new programs, solving complex tasks), will work more effective if the work process gives the opportunity for self-actualization. Technical professionals (people working with hardware, not creating new products) will work better with the help of material stimuli.

$\mathrm{H} 4$ : The fear of losing the job influences employees with traditional or conservative value setting, and those having children.

It is also possible to assume that the professionals who value flexible working schedule, independence in decision-making process and who value professional growth, are responsible people. Therefore, their sense of responsibility can be used as effective driving force for their productivity increase.

Current research applied quantitative paradigm of data collection and analysis. Data collection was conducted by a random sample with the use of online survey. The survey was programmed with Sawtooth software by professional programmer. The invitation to the survey was sent to 4225 respondents through emails and was available in personal accounts. In total, 1637 respondents took part in the survey and 1200 questionnaires were found analysable. The analysis was performed with the use of SPSS software. 
Database was analysed with the use of multiple linear regression analysis method. The analysis was aimed to create models that would connect work efficiency, work motivation and values of IT professionals. As the result, models which allowed to build an effective system of work motivation based on psychological, axiological and professional features of employees were proposed.

During the survey, 1200 respondents whose professional activity is associated with IT technologies were polled. Of them, $27 \%$ were female and $73 \%$ male. Age distribution of the sample population is presented in Figure 1. Collected data show that majority of Latvian IT specialists belong to the middle age group. It is possible to assume that significant part of young professionals work outside Latvia.

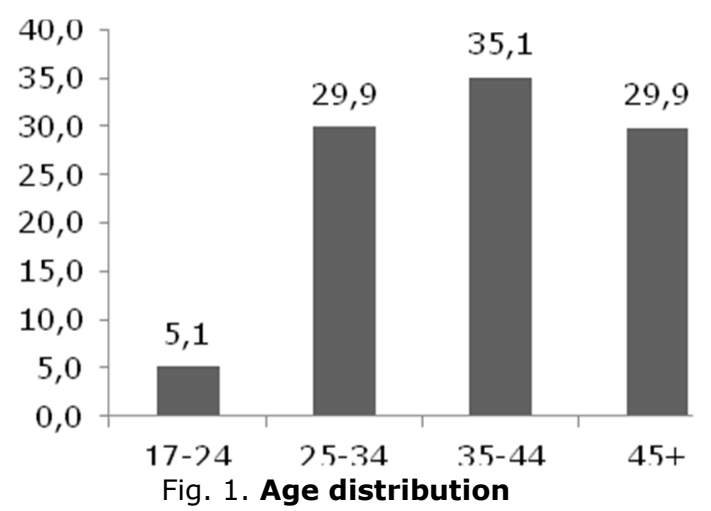

The majority of IT specialists that participated in the survey lived in Riga (68 \%), $30 \%$ - in other cities of Latvia and about $2 \%$ - in rural areas.

Approximately half of the respondents were employed in Latvian companies, $44 \%$ - in international companies and other $6 \%$ - in Latvian companies that had branches in other countries.

It is important to note that according to research results presented in Figure 2 absolute majority of surveyed professionals (over $70 \%$ ) believed that profession of IT specialist was considered prestigious and well paid. Only $2 \%$ respondents considered work in IT industry to be not prestigious and around $16 \%$ treated it as any other work. Thereby IT specialists as a part of creative class in Latvia were satisfied with their job and social status.

This logical deduction is confirmed by the analysis of respondents' answers to the question if they planned to change their job. As many as $72 \%$ of IT specialists in Latvia stated that they did not plan to change their work in a short-run and only $16 \%$ considered changing work then.

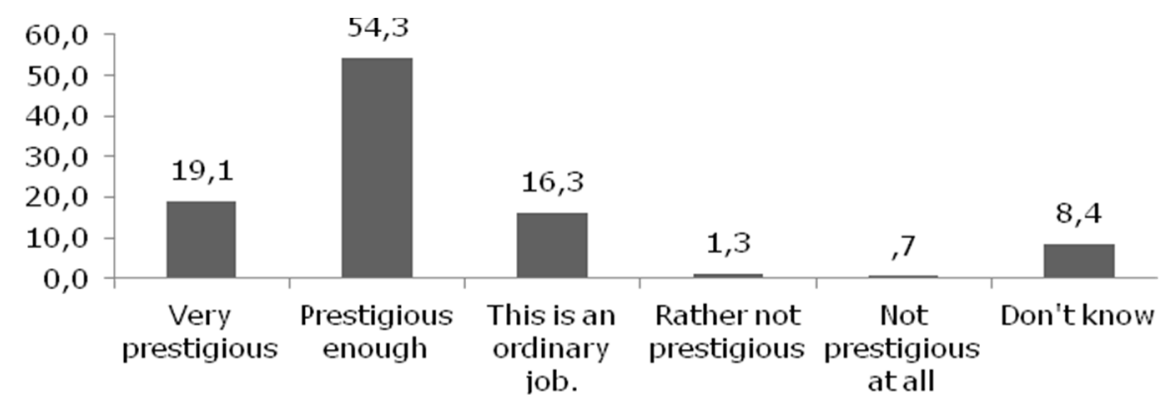

Fig. 2. Attitude to IT work prestige

Question: "From your point of view is it prestigious to be IT specialist in Latvia now"

Dependent variable in regression models is stimulus for labour efficiency growth. Independent variables are work motivation and values. Control variables are age, gender, satisfaction by income, work characteristics, presence of partner and amount of children and respondents' agency, or his/her confidence in his/her ability to control his/her life. 


\section{Work motivation of IT professionals in contemporary Latvia}

Work motivation is a latent variable that cannot be estimated and analysed by a direct question. In this regard, factor analysis method is applied in current research to study work motivation of IT specialists. Factor analysis was conducted by principal components method with their further rotation by Varimax method. This method of factor analysis allows to select factors that will not correlate with each other and explained the existing variance.

In order to have an ability to estimate work motivation using factor analysis, the survey included a block of questions that tested attitude of respondents. This block of questions aimed to find out what should work look like to be attractive for respondents. Following statements representing job characteristics were offered: 1) Having a complicated work that can bring satisfaction for your achievements; 2) Having an opportunity to improve your qualification; 3) Having good work conditions (good aeration, lighting, work space); 4) Having an opportunity to decide independently how to do your work; 5) Having an opportunity to realize your skills and perks fully; 6) Having a work that leaves enough time for personal life.

Factor analysis helped to identify three factors that characterize work motivation of IT specialists.

First factor is „Freedom and independence" that includes following characteristics:

- Having an opportunity to decide independently how to do your work;

- Having a work that leaves enough time for personal life.

This motivation factor assumes that employee has freedom to allocate his time and define how to do his work by himself. External control minimization and availability of their own time are very important factors characterizing quality of life of creative class. Therefore, this factor explains $25 \%$ of the overall variance in work motivation.

Second factor is "Professionalism and self-actualization". It is characterized by the following statements:

- Having a complicated work that can bring satisfaction for your achievements;

- Having an opportunity to realize your skills and perks fully.

This type of work motivation is associated with professional ambitions satisfaction and selfrealization in profession. In IT industry, high professionalism usually ensures successful career that assumes prestige and high income. This factor explains $15 \%$ of the overall variance in work motivation.

Third factor combines the following statements:

- Having an opportunity to improve your qualification;

- Having good work conditions (good aeration, lighting, work space).

This type of motivation is "Survival" when job is appreciated due to its ability to give a chance for gaining new skills and knowledge that will let to change work in future and to have work conditions that create comforTable and safe environment.

Selected factors were computed for each respondent. Values were saved in the data base in order to be used in building the model that will connect work motivation and stimuli for labour efficiency.

\section{Stimuli of labour efficiency growth detection}

Since stimuli that lead to the increase in efficiency growth of work of IT specialists are also latent variables, their detection and estimation was also based on the factor analysis conducted by the method of principal components. 
For this purpose, the question "Were there situations when you worked particularly well and fast? What factors made you work more effectively than usual?" was included in the questionnaire. This question suggested a choice of the following factors: great financial rewards, interesting complicated creative task, chance for career growth, clarity and lucidity of goals and desired result, high importance and prestige of the task, the respect of the team, approval of managers, crisis situation, understanding of responsibility, fear to be fired or lose the award, fear of not approval by team and management

Factor analysis allowed selecting five factors that describe stimuli that make IT professionals work more effectively.

First factor is „Financial stimuluses”. It includes such indicators as:

- Great financial rewards;

- Chance for career growth.

Thereby stimuli can be viewed either as a lump sum reward or as a career growth opportunity that also leads to the increase of financial prosperity.

Second factor consists of statements related to employees' responsibility for the results of their work. This stimuluscan be named as "Responsibility". It includes the following characteristics:

- Clarity and lucidity of goals and desired result;

- Crisis situation, understanding of responsibility.

Thus, it is possible to conclude that beside career growth and financial stimuli, effective work may be caused by crisis situation in case when an employee understands how to solve it and he is the only one who is able to solve it.

Third factor describes stimuli for creative people. It includes the respect of the team and managerial improvement. Doing something better than others, doing something that cannot be done by other team members is a very important stimulus for those who try to realize themselves professionally. This stimulus can be named "Increasing credibility".

Another stimulus for higher work efficiency is fear to be fired or lose the award and fear of disapproval by team and management. Despite the fact that this stimulus is based on negative emotions, it explains only $10 \%$ of variance of factors that influence the growth in work efficiency.

\section{Values of IT professionals}

Values are an essential part of personality. They affect personal estimation of most life situations and define behaviour including economic behaviour. Values show directivity of the human aimed at reaching of certain goals

Current research applies Schwarz technique to estimate values. For this purpose, questions from Schwarz questionnaire were included into survey (Schwarts, 1990). The respondents were asked to determine to which extent the below statements are relevant to themselves. 


\section{Questions to estimate values of IT professionals}

\begin{tabular}{|c|c|c|c|c|c|c|}
\hline Questions & $\begin{array}{c}\text { Very } \\
\text { much } \\
\text { like me }\end{array}$ & Like me & $\begin{array}{c}\text { Some- } \\
\text { what } \\
\text { like } \\
\text { me }\end{array}$ & $\begin{array}{l}\text { A little } \\
\text { like me }\end{array}$ & $\begin{array}{l}\text { Not like } \\
\text { me }\end{array}$ & $\begin{array}{c}\text { Not } \\
\text { like } \\
\text { me at } \\
\text { all }\end{array}$ \\
\hline $\begin{array}{l}\text { Thinking up new ideas and being creative is } \\
\text { important to him. He likes to do things in his } \\
\text { own original way. }\end{array}$ & 1 & 2 & 3 & 4 & 5 & 6 \\
\hline $\begin{array}{l}\text { It is important to him to be rich. He wants to } \\
\text { have a lot of money and expensive things. }\end{array}$ & 1 & 2 & 3 & 4 & 5 & 6 \\
\hline $\begin{array}{l}\text { It is important to him to live in secure } \\
\text { surroundings. He avoids anything that might } \\
\text { endanger his safety. }\end{array}$ & 1 & 2 & 3 & 4 & 5 & 6 \\
\hline $\begin{array}{l}\text { He seeks every chance he can to have fun. It } \\
\text { is important to him to do things that give } \\
\text { him pleasure. }\end{array}$ & 1 & 2 & 3 & 4 & 5 & 6 \\
\hline $\begin{array}{l}\text { It's very important to him to help the people } \\
\text { around him. He wants to care for their well- } \\
\text { being. }\end{array}$ & 1 & 2 & 3 & 4 & 5 & 6 \\
\hline $\begin{array}{l}\text { Being very successful is important to him. He } \\
\text { likes to impress other people. }\end{array}$ & 1 & 2 & 3 & 4 & 5 & 6 \\
\hline $\begin{array}{l}\text { He likes to take risks. He is always looking } \\
\text { for adventures. }\end{array}$ & 1 & 2 & 3 & 4 & 5 & 6 \\
\hline $\begin{array}{l}\text { It is important to him always to behave } \\
\text { properly. He wants to avoid doing anything } \\
\text { people would say is wrong. }\end{array}$ & 1 & 2 & 3 & 4 & 5 & 6 \\
\hline $\begin{array}{l}\text { He strongly believes that people should care } \\
\text { for nature. Looking after the environment is } \\
\text { important to him. }\end{array}$ & 1 & 2 & 3 & 4 & 5 & 6 \\
\hline $\begin{array}{l}\text { He thinks it is best to do things in traditional } \\
\text { ways. It is important to him to keep up the } \\
\text { customs he has learned. }\end{array}$ & 1 & 2 & 3 & 4 & 5 & 6 \\
\hline
\end{tabular}
Source: Schwarts, 1990

After the survey was conducted, factor analysis and Schwarz method were applied to select values inherent to IT specialists in Latvia.

\section{Hedonism}

- It is important to him to be rich. He wants to have a lot of money and expensive things.

- He seeks every chance he can to have fun. It is important to him to do things that give him pleasure.

- Being very successful is important to him. He likes to impress other people.

Motivational goal of this type is defined as pleasure and enjoying life.

Universalism

- Thinking up new ideas and being creative is important to him. He likes to do things in his own original way.

- It's very important to him to help the people around him. He wants to care for their well-being.

- He strongly believes that people should care for nature. Looking after the environment is important to him.

Motivational goal of this type is tolerance, understanding, protection of well-being of all people and nature.

\section{Traditions}

- It is important to him always to behave properly. He wants to avoid doing anything people would say is wrong.

- He thinks it is best to do things in traditional ways. It is important to him to keep up the customs he has learned.

- It is important to him to live in secure surroundings. He avoids anything that might endanger his safety. 
Motivational goal of this type is respect, acceptance and following the traditions and customs that exist in culture (respecting traditions, humility, piety, acceptance of one's fate, moderation).

Regression model that connects opportunities for work efficiency growth and employees' values takes for a dependent variable values of factors received as the result of factor analysis in order to select and evaluate stimuli for effective work. Thus, regression model is built for each stimulus. First model defines in what cases financial rewards are effective, while the second one shows for what type of employees it is effective to address to employees' responsibility, but the third model identifies efficiency of using employees' ambitions and the fourth one shows when fear is the most effective stimulus.

All models use values of the factors that identify and estimate work motivation (,Freedom and independence”, "Professionalism and self-actualization” and "Survival) and values (Hedonism, Universalism and Traditions) as independent variables.

As control variables' models use such variables as gender (a dummy variable 1 stands for male gender), number of children, satisfaction by income and work characteristics of respondents.

Work characteristics were estimated by responses on the question "Choose main tasks that you solve in your current working place": 1) Execution of work connected with equipment maintenance such as installation, repair, adjustment; 2) Checking work of programs/codes/applications/equipment; 3) Search and elimination of errors; 4) Creating new product (codes, programs) or design; 5) Solving problems connected with creation of new algorithms and programs; 6) Process optimization; 7) Finding new ways and approaches to problem solving.

Respondents whose work is mostly associated with equipment maintenance, checking work of programs/codes/applications/equipment and search and elimination of errors belong to technical specialists. Those who create new products (codes, programs) or solve problems connected with creation of new algorithms and programs belong to creative professionals. And finally, specialists who are engaged in process optimization and finding new ways and approaches to problem solving belong to super-creative core of professionals.

\section{Regression analysis results}

Table 2 presents four regression models that show connection between each of four stimuli for effective work with identified work motives, values, work characteristics, social and demographical characteristics of respondents. 
Models of labour productivity growth

\begin{tabular}{|c|c|c|c|c|}
\hline Variebles & $\begin{array}{l}\text { Model } 1 . \\
\text { Financial } \\
\text { rewards }\end{array}$ & $\begin{array}{l}\text { Model } 2 . \\
\text { Ambitions }\end{array}$ & $\begin{array}{c}\text { Model } 3 \text {. } \\
\text { Responsibility }\end{array}$ & $\begin{array}{l}\text { Model } 4 . \\
\text { Fear }\end{array}$ \\
\hline (Constant) &,- 173 &, 260 &, 346 &, 567 \\
\hline Age &,- 005 &,$- 009 * * *$ &,- 003 &,$- 007 * * *$ \\
\hline Gender (1-male) &,- 122 & ,008 &,- 106 &,- 047 \\
\hline Presence of partner &, $237 * * *$ &,- 123 & 027, & ,005 \\
\hline Number of children & 017 & ,061 & ,040 &, $063 * * *$ \\
\hline Agency & ,006 & 019 &,$- 047 * * *$ &,$- 043 * * *$ \\
\hline Satisfaction by income & ,015 &,- 012 & 019 &, 012 \\
\hline \multicolumn{5}{|c|}{ Work motivation } \\
\hline Freedom and independence & ,029 & 015 &, $092 * * *$ & ,041 \\
\hline $\begin{array}{l}\text { Professionalism and self- } \\
\text { actualization }\end{array}$ &,$- 076 * * *$ & ,049 &, $085 * * *$ & ,028 \\
\hline Survival &,- 006 &, $075 * * *$ &, 032 & ,046 \\
\hline \multicolumn{5}{|c|}{ Values } \\
\hline Hedonism &,$- 176 * * *$ &,- 024 & ,025 &,- 034 \\
\hline Universalism &,- 013 &,$- 073 * * *$ &,$- 129 * * *$ &, $083 * * *$ \\
\hline Traditions & ,038 &,$- 133 * * *$ &, $038 * * *$ &,$- 065 * * *$ \\
\hline \multicolumn{5}{|c|}{ Work characteristics } \\
\hline Technical specialists &,- 009 &, 021 & ,049 &,- 002 \\
\hline Creative professionals &,$- 066 * * *$ & ,019 &,- 017 &,$- 013 * * *$ \\
\hline $\begin{array}{l}\text { Super-creative core of } \\
\text { professionals }\end{array}$ &, 042 &, 010 & ,037 &,- 036 \\
\hline
\end{tabular}

First model analyses efficiency of financial rewards. Regression analysis results show that efficiency of financial stimuli is mostly correlated with family status, presence of constant partner or spouse. It is family status, but not presence of children or age, that makes respondents care about income. Moreover, financial rewards are effective for those IT specialists whose values are hedonism - wish to enjoy life. Obviously, contemporary professionals' pleasures are associated with material prosperity. Financial stimuli efficiency has negative correlation with work characteristics of "creative professionals". This means that for this group of professionals current stimulus is not effective.

Job that allows to realize one's ambitions (model 2) makes younger people work better as it has negative correlation with age variable. It influences those who appreciate the ability to increase their professional qualification in order to get more prestigious work later.

Noteworthy, this stimulus has significant link with two value variables - universalism and traditions. This link has same direction. Thus, possibility to realize ambitions attract both employees who are focused on approval from society and employees that care not only about their private but about public benefits, try to be useful for other people, society and nature.

Third model shows in what situations it makes sense to appeal to employees' responsibility in order to make him work more effectively. This stimulus can be effectively used when an employee has a low degree of agency when a person believes that there is not much depending on him or her personally, his life is governed by other people. Responsibility stimulus is important for those who appropriate work that brings freedom and independence and for those who value professional realization, who don't care about traditions but care about being useful for society. This type of people share universalism values. 
Fear as a stimulus (model 4) is effective for young employees that have children, those who respect traditions and follow social rules but not for those who care about environment. This stimulus has a significant negative linkage with work characteristics of creative professionals. So, it is not effective to apply this stimulus for this type of employees.

The research results have confirmed the hypotheses stated. The stimuli for increased work productivity have strong static bond with values and motivators of IT professionals. Material stimuli are not effective for people who create new creative products, for those who want the world to be better place. These stimuli work better with people sharing hedonistic values, having sTable job more of a hardware service area or routine tasks.

Young and creative people perform better if they have ambitious tasks and goals combined with sense of responsibility instead of full control.

\section{Conclusion}

Research results show that IT professionals in Latvia belong to different generations. However, only the youngest employees have particular stimuli for labour productivity growth. Employees belonging to other age groups are not a significant variable.

Noteworthy, young IT professionals cannot be observed as a homogeneous group. Among them the authors distinguished IT specialists that can be named creative professionals. Their work is connected with creating new products, processes and algorithms. For this subgroup financial stimuli such as lump sum rewards, promises of career promotion and threats of dismissal are not effective.

Economic behaviour of young IT specialists may evolve when their marital status changes or children get born. However, values have greater influence on their motivation. People focused on hedonistic values such as wealth, success and pleasure are ready to perform better for financial rewards. People that try to follow traditions and avoid behaviour that is not approved by other people can be influenced by threats of dismissal and supervisor disapproval.

For all the IT specialists regardless of age and work characteristics important motivation factors are professional realization and freedom and independence, ability to define how to do their work and when to work. As a consequence of this type of motivation effective stimuli for labour productivity growth are awareness of task importance, understanding responsibility between colleagues and respect from co-workers. Unfortunately, the variety of nonfinancial stimuli and negative influence of enforcement are rarely realized by employers. It creates unfavourable work environment, decreases work efficiency and leads to dismissal of the most talented IT specialists.

One of the most important findings of the research is absence of gender differences both in work motivation and labour efficiency stimuluses. This suggests that gender differences are levelled among IT professionals. For modern Latvian women employed in IT industry professional realization, freedom and independence, respect from co-workers are as important as for men. Women are also attracted by complicated ambitious tasks, opportunity to do something important and extraordinary.

Hence professionals employed in IT industry build a new professional environment in Latvia which is characterized by meritocracy, equality, professionalism, freedom and independence. This environment demands new motivational systems of management. Presumably, this professional culture will diffuse to other professional groups and lead to significant changes in Latvian society. 


\section{References}

1. Chaix-Couturier, C., Durand-Zaleski, I., Jolly, D., Durieux, p. (2000). Effects of Financial Incentives on Medical Practice: Results from a Systematic Review of the Literature and Methodological Issues. Int J Qual Health Care, 12,pp. 133-42.

2. Chowdhury, M. (2008). Enhancing Motivation and Work Performance of the Salespeople: The Impact of Supervisors' Behavior. African Journal of Business Management. 1.pp. 238-243

3. Eurostat (2018). Proportion of ICT Specialists in Total Employment, 2017. Retrieved December 20, 2018 from https://ec.europa.eu/eurostat/statistics-explained/index.php/ICT_specialists_in_employment

4. Drake, K. (2017). The Motivation to Stay Motivated/ Nursing Management (Springhouse), Volume 48, Issue 12. pp. 56-65. doi: 10.1097/01.NUMA.0000526921.77464.16

5. Deci, E. L., \& Ryan, R. M. The "What" and "Why" of Goal Pursuits: Human Needs and the Selfdetermination of Behavior. Psychological Inquiry, 2000, 11, pp. 227-268.

6. Frager, R., Fadiman J. Personality and Personal Growth, Harper \& Row, 1976.

7. Frager, R., Maslow A. Motivation and Personality, Pearson Longman, 1987.

8. Glaser, M., Tailoring Performance Measurement to Fit the Organization: From Generic to Germane, Public Productivity \& Management Review, 1991, Vol. 14, No. 3, pp. 303-319.

9. Jarkas, A.M. and C.G. Bitar, Factors Affecting Construction Labor Productivity in Kuwait. Journal of Construction Engineering and Management, 138(7), pp.811-820., 2012.

10. Khan, F. Saleem, and M. Umer, „Effectiveness of Worker Motivational Techniques on Construction Project Safety, Productivity and Quality Performance," in Proc. 6th International Conf. on Construction in the 21st Century (CITC-VI): Construction Challenges in the New Decade, Kuala Lumpur, Malaysia, July 5-7, 2011.

11. Kasser, T., Ryan, R. M. A Dark Side of the American Dream: Correlates of Financial Success as a Central Life Aspiration. Journal of Personality and Social Psychology, 1993, 65, pp. 410-422

12. Meyer, p. Preliminary Estimates of Multifactor Productivity Growth. Monthly Labor Review, June 2005, pp. 32-43.

13. Monese, L.N. and W.D. Thwala, Motivation as a Tool to Improve Productivity on the Construction Site. Available at: [Accessed 19 March 2015]. 2014.

14. Schwarts, S. H. Towards a Theory of the Universal Structure and Content of Values: Extention and Crosscultural Replications / S. H. Schwartz, W. Bilsky // Journal of Personality and Social Psychology.1990, № 3, pp. 878-891.

15.Trahair, R., Zaleznik, A. Elton Mayo: The Humanist Temper. Transaction Publishers, 2005.

16.Znotina, D., Jermolajeva, E. Labour Productivity in the Regions of Latvia, European Integration Studies. 2011. No 5, pp. 1-7. 